16 \# Co-corresponding authors:

17 Maria Adelaida Gomez

Tel: +57 (2) 5552164 .

Fax: $+57(2) 5552638$

Stuart McDougall

Tel: +44 (1) 665608405 clinical responsibility for patients.

\title{
Validated ICP-MS method for measurement of plasma and intracellular antimony concentrations applied to pharmacokinetics of meglumine antimoniate
}

\author{
Diana J. Garay-Baquero ${ }^{1,2}$ David E. Rebellon-Sánchez ${ }^{1}$, Miguel D. Prieto ${ }^{1}$, Lina Giraldo-Parra ${ }^{1,4}$, \\ Adriana Navas ${ }^{1}$, Sheryl Atkinson ${ }^{3}$, Stuart McDougall ${ }^{3 \#}$, Maria Adelaida Gómez ${ }^{1,4 \#}$ \\ 1. Centro Internacional de Entrenamiento e Investigaciones Médicas, CIDEIM, Carrera 125 No. \\ 19 - 225 Cali, Colombia. \\ 2. Clinical and Experimental Sciences, Faculty of Medicine, University of Southampton, General \\ Hospital Southampton, SO16 6YD, Southampton, UK \\ 3. Arcinova, Alnwick, NE66 2DH, Northumberland, UK \\ 4. Universidad ICESI, Cali, Colombia.
}

\section{Running title: ICP-MS for measurement of plasma and intracellular antimony}

E-mail address: mgomez@cideim.org.co

E-mail address: stuart.mcdougall@arcinova.com

Keywords: ICP-MS, meglumine antimoniate, antimony, leishmaniasis

The authors confirm that the Principal Scientific Investigator for this paper was Maria Adelaida Gómez and that the Principal Medical Investigator was Miguel Dario Prieto and that he had direct 
medRxiv preprint doi: https://doi.org/10.1101/2020.09.15.20194647; this version posted September 18, 2020. The copyright holder for this preprint (which was not certified by peer review) is the author/funder, who has granted medRxiv a license to display the preprint in perpetuity.

It is made available under a CC-BY-ND 4.0 International license .

\section{What is already known about this subject}

33

34

35

36

37

38

39

40

41

42

43

\section{$44 \quad$ What this study adds}

45

46

47

48

49

50

51 available.

- Antimonial drugs are the mainstay treatment for cutaneous leishmaniasis of which systemically administered pentavalent antimonials ( $\mathrm{SbV}$ ) are widely used, however the pharmacokinetics (PK) of these drugs at the site of action is unknown.

- A wide range of analytical strategies have been used to quantify antimony in biological samples and atomic absorption spectroscopy is the most employed technique, however, no standardized methods for determination of intracellular concentrations of antimony were

- Relationships between plasma and intracellular drug concentrations remain unknown for most antiparasitic drugs, and PK studies rely on plasma drug concentrations assuming these act as surrogates of intracellular concentrations.

- We have developed and validated a reproducible and accurate ICP-MS method for the quantification of total antimony in human plasma and peripheral blood mononuclear cells (PBMCs) in accordance with the European Bioanalysis Forum (EBF) recommendations.

- This method was successfully used to compare pharmacokinetic curves of antimony in plasma and intracellular compartments, in samples collected from patients undergoing treatment for cutaneous leishmaniasis with meglumine antimoniate. 


\section{ABSTRACT}

\section{$53 \quad$ Aim}

54 A high-throughput method using inductively coupled plasma mass spectrometry (ICP-MS) was 55 developed and validated for the quantitative analysis of antimony in human plasma and peripheral 56 blood mononuclear cells (PBMCs) from patients with cutaneous leishmaniasis undergoing treatment 57 with meglumine antimoniate.

\section{Methods}

59 For this study, antimony was digested in clinical samples with 1\% TMAH / 1\% EDTA and indium 60 was used as internal standard. Calibration curves for antimony, over the range of 25 to $10000 \mathrm{ng} / \mathrm{mL}$ 61 were fitted to a linear model using a weighting of $1 /$ concentration $^{2}$. Accuracy, precision and stability 62 were evaluated.

\section{Results}

64 Taking the lower limit of quantitation (LLOQ) to be the lowest validation concentration with 65 precision and accuracy within $20 \%$ (25\% at the LLOQ), the current assay was successfully validated 66 from 25 to $10000 \mathrm{ng} / \mathrm{mL}$ for antimony in human plasma and PBMCs. Dilution studies demonstrated 67 that concentrations up to $100000 \mathrm{ng} / \mathrm{mL}$ of antimony in plasma were reliably analyzed when diluted 68 into the calibration range.

\section{Conclusion}

70 This protocol will serve as a baseline for future analytical designs, aiming to provide a reference 71 method to allow inter-study comparisons.

72

73 


\section{INTRODUCTION}

77

78

79

80

81

82

83

84

85

86

87

88

89

90

91

92

93

94

95

96

97

98

99

100

101

102

103

104

105

106

107

108

109

110

111

112
Leishmaniasis is a group of diseases caused by protozoan parasites of the genus Leishmania, which can cause cutaneous, mucosal or visceral manifestations depending on the infecting species and the host immune status ${ }^{1,2}$. According to the most recent report from the World Health Organization (WHO), leishmaniasis is endemic across all continents. Despite an elevated proportion of suspected underreporting, 700000 to over 1200000 new cases are estimated to occur annually ${ }^{2,3}$.

Leishmania is an intracellular parasite that invades and replicates predominantly within phagocytic cells (primarily macrophages), providing a "protected" environment against host defenses and a barrier to drug exposure. Antimonial drugs are the mainstay treatment for cutaneous leishmaniasis of which systemically administered pentavalent antimonials $\left(\mathrm{Sb}^{\mathrm{V}}\right)$ are widely used in the Americas and as intradermal injections in the Old World ${ }^{4}$. Sodium stibogluconate (Pentostam ${ }^{\circledR}$ ) and meglumine antimoniate (Glucantime ${ }^{\circledR}$ ) are the synthetic compounds used for pentavalent antimonial therapy. Their efficacy is highly variable, according to the infecting species, parasite subpopulations, host responses and therapeutic regimens ${ }^{5-7}$. Antileishmanial drugs need to be distributed to the parasitetargeted tissues (primarily skin, liver, spleen and bone marrow depending on the infecting species), internalized into host cells and distributed to the phagolysosomal compartment where the parasite resides ${ }^{8}$. Although antimonials have been used over decades, the pharmacokinetics (PK) and pharmacodynamics (PD) of these drugs are not completely understood ${ }^{9,10}$. Few studies have described antimonial PK in the context of human leishmaniasis ${ }^{11,12}$ and the plasma and intracellular PK parameters involved in the therapeutic response remain unknown.

Atomic absorption spectrometry is the most common method used to quantitatively determine antimony levels in biological specimens such as blood and urine from patients undergoing antimonial therapy in pharmacokinetic studies ${ }^{11,13}$. Although, a validated analytical method for quantification of arsenic and antimony in liposomes was previously developed using inductively coupled plasmaoptical emission spectrometry ${ }^{14}$, there is not a validated method available for intracellular antimony determination. Inductively coupled plasma mass spectrometry (ICP-MS) is an ultrasensitive and selective method that allows quantification levels in the order of parts per trillion, with a wide dynamic range of nine orders of magnitude and high throughput ${ }^{15}$. Interferences are relatively low and matrix effects can be minimized by using internal standard controls ${ }^{16,17}$. ICP-MS has been widely used in pharmacokinetic studies in humans of metal-based formulations such as arsenic, gadolinium, and some antineoplastic drugs ${ }^{18-22}$. Its convenience and reduced time-consumption make this technique a powerful tool for quantitative determination of antimony in clinical samples at intracellular levels.

In this study, we present a scientifically validated analytical protocol for determination of total antimony in human plasma and peripheral blood mononuclear cells from patients with cutaneous leishmaniasis undergoing treatment with meglumine antimoniate (Figure 1).

$<$ Figure 1> 


\section{METHODS}

\section{Reagents}

117 ICP grade antimony (Batches 884136D and BCBP51619V) and indium (Batch 833920k) were 118 obtained from Alfa Aesar (Heysham, UK) and Sigma Aldrich (Buchs, Switzerland). Electronic grade 119 tetramethylammonium Hydroxide (TMAH) was purchased from Alfa Aesar and 120 ethylenediaminetetraacetic acid (EDTA) from (Sigma). Human plasma for validation studies was 121 obtained from Biochemed (Winchester, USA). High purity ( $>99.999 \%)$ argon gas (BOC Gases, UK) 122 was used for ICP-MS analysis. ASTM Type I ultra-pure water ( $>18 \mathrm{M} \Omega$ ) was provided in-house by 123 an Elga Purelab-Ultra system (Veolia Water Technologies, UK).

\section{Clinical samples and study design}

Plasma samples and peripheral blood mononuclear cells (PBMCs) were obtained from EDTA anticoagulated blood from patients with cutaneous leishmaniasis (CL, $n=5)$. All CL patients had parasitological confirmation of infection and were recruited at Centro Internacional de Entrenamiento e Investigaciones médicas (CIDEIM) outpatient clinics in Cali, Colombia. CL patient samples were collected from a cohort study that evaluates the relationship between antileishmanials PK, immune response signatures and clinical responses (CIDEIM IRB Study code CIEIH-1258). The study was reviewed and monitored by CIDEIM ethics committee in accordance with national (resolution 8430, República de Colombia, Ministry of Health, 1993) and international (Declaration of Helsinki and amendments, World Medical Association, Fortaleza, Brasil, October 2013) guidelines.

Participants were treated with intramuscular meglumine antimoniate (Glucantime ${ }^{\circledR}[81 \mathrm{mg} \mathrm{Sb} / \mathrm{mL}]$; (Sanofi-Aventis) during 20 days with a dose of $20 \mathrm{mg} / \mathrm{kg}$ up to a maximum dose of $1620 \mathrm{mg}$ of Sb(V), equivalent to a $20 \mathrm{~mL}$ injection. The median adherence to the indicated regime was $85 \%$ (75\% $100 \%$ ). Peripheral blood samples were collected during the last day of treatment at the following time-points: before dose and at $0.5,1,1.5,2,3,5,8,12$ and 24 hours after drug administration. In total, samples from 5 CL patients were included in this study for quantification (Table 1).

$<$ Table 1>

\section{Plasma procurement and $\mathrm{PBMC}$ isolation}

Venous blood was collected in EDTA vacutainer tubes and plasma was prepared by centrifuging 10 $\mathrm{mL}$ of blood at $1300 \mathrm{x} \mathrm{g}$ for 10 minutes at room temperature. An aliquot of $3 \mathrm{~mL}$ of plasma was transferred to a fresh tube and centrifuged again under the same conditions. The plasma was transferred to a new tube and stored at $-80^{\circ} \mathrm{C}$. Remaining plasma and blood cells were gently mixed with PBS to complete $20 \mathrm{~mL}$ final volume. Blood/PBS mix was carefully layered on top of $10 \mathrm{~mL}$ Ficoll-Hypaque 1077 gradient (Sigma) in a $50 \mathrm{~mL}$ centrifuge tube and centrifuged at $400 \mathrm{x}$ g for $35 \mathrm{~min}$ at room temperature $\left(\mathrm{RT}=19-23{ }^{\circ} \mathrm{C}\right)$. The plasma layer was carefully removed, and the mononuclear cells layer was transferred to a separate centrifuge tube. Cells were washed with at least three volumes of PBS. Cells were subsequently centrifuged at $400 \mathrm{x}$ g for $15 \mathrm{~min}$ at RT. Then, the supernatant was discarded and the pellet was resuspended in $200 \mu \mathrm{L}$ of $25 \% \mathrm{TMAH}$ and stored at approximately $-80^{\circ} \mathrm{C}$ until use. This PBMC preparation is referred as PBMC matrix for method development. 


\section{ICP-MS analysis}

The analyses were performed in a dedicated ACDP (UK Advisory Committee on Dangerous Pathogens) Class II bio-facility and all sample processing and digestion was performed inside Class I HEPA filtered biosafety cabinets to minimize the risks of contamination. All elemental reference standard preparations ( $\mathrm{Sb}$ and $\mathrm{In}$ ) were performed in a separate and dedicated laboratory to further eliminate the potential for sample contamination

\section{Instrumentation and system suitability}

Antimony and indium (internal standard), each have two stable isotopes: ${ }^{121} \mathrm{Sb}$ and ${ }^{123} \mathrm{Sb}$, and ${ }^{113} \mathrm{In}$ and ${ }^{115} \mathrm{In}$, respectively. Of these, ${ }^{121} \mathrm{Sb}$ and ${ }^{115} \mathrm{In}$ are most abundant and, therefore, were used to quantify antimony and indium, as internal standard, by ICP-MS.

All measurements were performed using an Agilent 7700x series ICP-MS, and used to quantify antimony (mass 121) relative to the indium internal standard (mass 115), following infusion of the sample into the ICP-MS via an integrated sample introduction system (ISIS) and micromist nebulizer. The operating system was the ICP MassHunter, version B.01.03 (Agilent). Operating parameters are listed in Table 2. The regression and quantitation procedures were performed using Watson LIMS version 7.5 SP1 (Thermo Fisher Scientific, USA).

\section{$<$ Table 2>}

Prior to initiating any run on the system, an ICP-MS tune test was performed by analyzing a calibration mix containing cerium, cobalt, lithium, magnesium, thallium and yttrium (10 ppm, Agilent) in Tune mode. The raw counts should exceed 1000 units for each element and the variability (\% relative standard deviation, $\% \mathrm{RSD}$ ) should be under $10 \%$ for the system to be classified as suitable. Additionally, a system suitability test (SST) was executed by running two antimony dilutions; the low SST solution was $0.5 \mathrm{ng} / \mathrm{mL}$ and the high SST solution was $200 \mathrm{ng} / \mathrm{mL}$. These dilutions were prepared using the indium internal standard solution (InISS) as matrix. InISS was a dilution at $2 \mathrm{ng} / \mathrm{mL}$ of Indium in 1\%TMAH / 1\%EDTA. The blank was a dilution of $2 \%$ human plasma matrix in $1 \% \mathrm{TMAH} / 1 \%$ EDTA. The raw antimony count of the blank must be $\leq 25 \%$ of the low SST raw count.

\section{Preparation of calibration and quality control standards}

Calibration standards were prepared by mixing an aliquot of the commercial antimony stock solution with purified water to yield eight calibration standards $2.5,4,25,50,250,500,725,1000 \mu \mathrm{g} / \mathrm{mL}$. Similarly, a set of five quality control (QC) standards were prepared separately with purified water to produce $2.5,5,50,750,10000 \mu \mathrm{g} / \mathrm{mL}$ concentrations.

\section{Preparation of calibration samples}

Calibration stock standards were mixed with filtered control human plasma in a rotary mixer for at least $30 \mathrm{~min}$ at $30 \mathrm{rpm}$ to yield nominal antimony concentrations of 25, 50, 250, 500, 2500, 5000, 7500 and $10000 \mathrm{ng} / \mathrm{mL}$. Calibration samples were either used fresh or stored frozen at either -20 or - 
$80 \pm 10^{\circ} \mathrm{C}$ for no longer than 56 days. Calibration samples used to determine stability were freshly prepared.

\section{Preparation of validation samples}

Plasma validation samples were prepared by mixing QC standard solutions with human plasma in a rotary mixer for at least $30 \mathrm{~min}$ at $30 \mathrm{rpm}$ to give nominal antimony concentrations of 25 (QCLLOQ), 50 (QCL), 500 (QCM), $7500(\mathrm{QCH})$ and $100000 \mathrm{ng} / \mathrm{mL}$ (DQC). Validation samples were stored frozen at either -20 or $-80 \pm 10^{\circ} \mathrm{C}$ for no longer than 56 days.

PBMC validation samples were prepared by mixing an aliquot $(100 \mu \mathrm{L})$ of the plasma validation samples QCLLOQ, QCL, QCM, and QCH with and an aliquot of control PBMC matrix $(100 \mu \mathrm{L})$ at the time of sample digestion.

\section{Antimony digest preparation}

Analytical samples were thawed at room temperature and vortex mixed. For plasma analysis, an aliquot of each plasma sample $(100 \mu \mathrm{L})$ was mixed with $4.90 \mathrm{~mL}$ of InISS in a rotary mixer for 30 minutes at room temperature. For PBMC analysis, an aliquot of each PMBC sample (100 $\mu \mathrm{L}$ PBMC matrix and $100 \mu \mathrm{L}$ plasma validation sample) was added to $4.80 \mathrm{~mL}$ of InISS and mixed for 30 min. An aliquot of each processed sample was then analyzed by ICP-MS together with quality control samples and a multilevel calibration.

Intracellular antimony concentration was calculated by dividing the total estimated antimony content in the cell pellet by the total cell volume (number of PBMCs per pellet $\times 283 \mathrm{fL}$, where $283 \mathrm{fL}$ is the average volume of a single $\mathrm{PBMC}^{23}$ )

\section{Dilution}

A 1:10 dilution of the samples was prepared by adding $0.5 \mathrm{~mL}$ of each digested sample to $4.5 \mathrm{~mL}$ of InISS. Samples were vortex mixed for approximately 10 seconds, tumbled for at least 30 minutes on rotary mixer and then transferred to a sample rack for analysis by ICP-MS.

\section{RESULTS}

\section{Assay specificity and calibration}

The spectrographic interference from antimony on the indium response was within acceptance criteria ( $\leq 5.00 \%$ of the mean peak area of indium matrix blank response in the run). Similarly, the spectrographic interference from indium on the antimony response was within acceptance criteria $(\leq$ $25.0 \%$ of the mean peak area of the LLOQ of antimony response in the run. A linear model method using a weighting of $1 /$ concentration $^{2}$ was selected for calibration of antimony in human plasma and a representative calibration curve is presented in Figure 2.

$<$ Figure 2 $>$

The calibration curve parameters obtained throughout the validation study are listed in Table 3 . 
$<$ Table 3>

Quality control samples, prepared in plasma at antimony concentrations $50,500,7500 \mathrm{ng} / \mathrm{mL}$ were used to demonstrate the performance of the analytical assay. The relative bias of the back-calculated concentrations of antimony within the acceptance criteria ranged between $-2.60 \%$ and $3.51 \%$ for 7 analytical runs ran over 132 days (Table 4).

$<$ Table 4>

Quality control (QC) data was obtained during the validation process. Quality control samples at low $(50 \mathrm{ng} / \mathrm{mL})$, medium $(500 \mathrm{ng} / \mathrm{mL})$ and high $(750 \mathrm{ng} / \mathrm{mL})$ concentration were evaluated by duplicate over analytical runs 2 to $6(\mathrm{n}=10)$. The mean antimony concentration for the low concentration control was $50 \mathrm{ng} / \mathrm{mL}(\mathrm{SD}=3.89$; \%CV=7.78; \%Bias=0.00); $494 \mathrm{ng} / \mathrm{mL}(\mathrm{SD}=9.91 ; \% \mathrm{CV}=2.01 ; \% \mathrm{Bias}=-$ 1.20) for the medium concentration control and $7520 \mathrm{ng} / \mathrm{mL}(\mathrm{SD}=189 ; \% \mathrm{CV}=2.51 ; \% \mathrm{Bias}=0.27)$ for the high concentration control sample. The impact of carry-over was assessed at the start and the end of every run containing a calibration curve. The mean percentage carry-over was $10.6 \%$ and within the acceptance criteria $(\leq 25.0 \%$ difference).

\section{Assay variability}

Accuracy and within-run precision for the validation of the antimony assay are summarized in Table 5. The accuracy ranged from -1.20 to $1.20 \%$ of nominal values. At all concentration levels of antimony, the ranges of accuracy and precision were within established acceptance criteria.

$<$ Table 5>

Accuracy and within-run precision for the validation of the antimony assay in PBMC are summarized in Table 6 . The accuracy ranged from -12.2 to $20.8 \%$ of nominal values. At all concentration levels of antimony, the ranges of accuracy and precision were within established acceptance criteria

$<$ Table 6>

\section{Antimony stability}

The stability of antimony in plasma was established following storage at room temperature for 24 hours using plasma samples spiked with $50 \mathrm{ng} / \mathrm{mL}$ or $7500 \mathrm{ng} / \mathrm{mL}$ of antimony standards defined as low and high concentration quantification controls, respectively. Six replicates were analyzed for each concentration and condition. No significant changes in the plasma antimony concentrations were observed after this storage period. The mean concentration for the low concentration control was 50.4 $\mathrm{ng} / \mathrm{mL}(\mathrm{SD}=4.28 ; \% \mathrm{CV}=8.49 ; \% \mathrm{Bias}=0.80)$ and $7550 \mathrm{ng} / \mathrm{mL}(\mathrm{SD}=123 ; \% \mathrm{CV}=1.63 ; \% \mathrm{Bias}=0.67)$ for the high concentration control.

Additionally, stability of antimony in plasma was assessed following four freeze/thaw cycles at $-20^{\circ} \mathrm{C}$ and $-80^{\circ} \mathrm{C} \pm 10^{\circ} \mathrm{C}$ utilizing plasma samples spiked with $50 \mathrm{ng} / \mathrm{mL}$ or $7500 \mathrm{ng} / \mathrm{mL}$ of antimony standard. Six replicates were analyzed for each concentration and condition and the accuracy and precision for quantitation of antimony under these conditions was evaluated. Subsequent to four freeze/thaw cycles at $-20^{\circ} \mathrm{C}$ the mean concentration for the low concentration control was $48.3 \mathrm{ng} / \mathrm{mL}$ $(\mathrm{SD}=2.09 ; \% \mathrm{CV}=4.33 ; \% \mathrm{Bias}=-3.40)$ and $7290 \mathrm{ng} / \mathrm{mL}(\mathrm{SD}=314 ; \% \mathrm{CV}=4.31 ; \% \mathrm{Bias}=-2.80)$ for the 
high concentration control. At $-80^{\circ} \mathrm{C}$ the mean concentration for the low concentration control was $46.3 \mathrm{ng} / \mathrm{mL} \quad(\mathrm{SD}=1.18 ; \% \mathrm{CV}=2.55 ; \% \mathrm{Bias}=-7.40)$ and $7530 \mathrm{ng} / \mathrm{mL} \quad(\mathrm{SD}=107 ; \% \mathrm{CV}=1.42$; $\%$ Bias $=0.40$ ).

Stability of antimony in plasma was established following storage at approximately $-20^{\circ} \mathrm{C}$ and $-80^{\circ} \mathrm{C}$ $\pm 10^{\circ} \mathrm{C}$ for 56 days. Six replicates were analyzed for each concentration and condition and the accuracy and precision for quantitation of antimony under these conditions was evaluated. Storage of plasma samples at $-20^{\circ} \mathrm{C}$ for 56 days resulted in a mean concentration for the low concentration control of $48.7 \mathrm{ng} / \mathrm{mL}(\mathrm{SD}=1.66 ; \% \mathrm{CV}=3.41 ; \%$ Bias=-2.60) and $7450 \mathrm{ng} / \mathrm{mL}(\mathrm{SD}=80.7 ; \% \mathrm{CV}=1.08$; $\%$ Bias $=-0.67$ ) for the high concentration control. Storage at $-80^{\circ} \mathrm{C}$ for the same period resulted in a mean concentration for the low concentration control of $48.2 \mathrm{ng} / \mathrm{mL}(\mathrm{SD}=2.30$; \%CV=4.77; \%Bias=$3.60)$ and $8150 \mathrm{ng} / \mathrm{mL}(\mathrm{SD}=315 ; \% \mathrm{CV}=3.87 ; \% \mathrm{Bias}=8.67)$ for the high concentration control.

Stability of antimony in processed human plasma samples after storage at room temperature for 120 hours and 35 days at room temperature was also evaluated. Six replicates were analyzed for each concentration. Storage for 120 hours resulted in a mean concentration for the low concentration control of $52.0 \mathrm{ng} / \mathrm{mL}(\mathrm{SD}=2.47 ; \% \mathrm{CV}=4.75 ; \% \mathrm{Bias}=4.00)$ and $7820 \mathrm{ng} / \mathrm{mL}(\mathrm{SD}=128 ; \% \mathrm{CV}=1.64$; $\%$ Bias $=4.27$ ) for the high concentration control. Following storage of the processed samples for 35 days at room temperature resulted in a mean concentration for the low concentration control of 48.9 $\mathrm{ng} / \mathrm{mL}(\mathrm{SD}=1.14 ; \% \mathrm{CV}=2.33 ; \% \mathrm{Bias}=-2.20)$ and $7630 \mathrm{ng} / \mathrm{mL}(\mathrm{SD}=158 ; \% \mathrm{CV}=2.07 ; \% \mathrm{Bias}=1.73)$ for the high concentration control.

\section{Influence of dilution on the quantitation of antimony in plasma}

Plasma antimony levels can reach peak concentrations over $40 \mu \mathrm{g} / \mathrm{mL}$ following intramuscular administration of meglumine antimoniate ${ }^{11}$, therefore plasma dilution is usually required for antimony quantification. The accuracy and precision results for quantitation of antimony following plasma sample dilution were evaluated over one analytical run and six replicates were measured. Plasma concentrations up to $100000 \mathrm{ng} / \mathrm{mL}$ were reliably analyzed when diluted 1:10 (v:v) into the calibration range of the assay. The mean quantified concentration of spiked plasma was $105000 \mathrm{ng} / \mathrm{mL}$ $(\mathrm{SD}=2400 ; \% \mathrm{CV}=2.29 ; \% \mathrm{Bias}=5.00)$.

The accuracy and precision results for quantitation of antimony in digested dilutions prepared from plasma samples were also evaluated. Concentrations up to $100000 \mathrm{ng} / \mathrm{mL}$ were reliably analyzed when diluted 1:10 (v:v) into the calibration range of the assay. The mean concentration was 102000 $(\mathrm{SD}=816 ; \% \mathrm{CV}=0.80 ; \%$ Bias $=2.00, \mathrm{n}=6)$.

Antimony determination in clinical samples of patients undergoing antileishmanial treatment with meglumine antimoniate

The ICP-MS quantitative method validated in this study was applied to determine the plasma and intracellular levels of antimony in patients undergoing treatment for cutaneous leishmaniasis with meglumine antimoniate. Levels of antimony were measured at the end of the treatment (day 20) and evaluated up to 24 hours following drug administration. Figure 3A-E presents the plasma and intracellular (PBMCs) concentration-time curves of five adult patients. 


\section{Discussion}

A wide range of analytical strategies have been used to quantify antimony in biological samples, and atomic absorption spectroscopy, using diverse atomization configurations, is the most employed technique ${ }^{24,25}$. Previously, our group standardized and applied an electrothermal atomic absorption spectrometry method to quantify antimony in plasma and urine samples after administration of intramuscular Glucantime ${ }^{\circledR}{ }^{11}$. However, no standardized methods for determination of intracellular concentrations of antimony were available to date, which limited the study of pharmacokinetics of antimonial compounds at the site of drug action during antileishmanial chemotherapy.

We have developed and scientifically validated a reproducible and accurate ICP-MS method for the quantification of total antimony in human plasma and PBMCs in accordance with the European Bioanalysis Forum (EBF) recommendations. Antimony levels in clinical samples were quantitatively determined by ICP-MS following digestion in 1\%TMAH / 1\% EDTA, using indium as the internal standard. Accuracy and within-run precision were within acceptance limits. The maximum run size for this assay (assay robustness) was 240 injections per batch. Antimony was stable in human plasma at room temperature for at least 24 hours, at approximately $-20^{\circ} \mathrm{C}$ or $-80^{\circ} \mathrm{C} \pm 10^{\circ} \mathrm{C}$ for at least 56 days and following at least four freeze/thaw cycles. In addition, processed samples were stable for at least 35 days at room temperature. Dilution evaluation demonstrated that concentrations up to 100000 $\mathrm{ng} / \mathrm{mL}$ of antimony could be reliably analyzed when diluted into the calibration range. These data show that our method has adequate specifications to reliably perform pharmacokinetic studies of total plasmatic and intracellular antimony. Accuracy and precision for PBMC was not as high as in plasma, but met the predefined scientific validation assay acceptance criteria (+/- $25 \%$ at LLOQ).

The main limitation of this method is that it does not allow $\mathrm{Sb}^{\mathrm{III}}$ and $\mathrm{Sb}^{\mathrm{V}}$ speciation. Antimony-based antileishmanial therapy is administrated as pentavalent antimony, which is rapidly absorbed reaching peak plasma concentration between $0.5 \mathrm{~h}$ to $2 \mathrm{~h}$. However bio reduction to the trivalent form is required for the antileishmanial activity ${ }^{9}$. It has been proposed that this redox process can occur in the host cell phagolysosome where the parasites reside, or in the parasitic cytosol ${ }^{26} . \mathrm{Sb}^{\mathrm{III}}$ induces an increase of intracellular $\mathrm{Ca}^{2+}$ and finally apoptosis. Thus, antileishmanial activity is highly dependent upon intracellular mechanisms. Although this method cannot discriminate antimony species, this is the first validated method available for intracellular quantification of antimony.

We generated pharmacokinetic curves of antimony in PBMCs from patients undergoing meglumine antimoniate antileishmanial treatment at last day of treatment and compared them to plasma concentration-time curves. Intracellular antimony concentration was over seven times higher than plasma before the last dose was administered showing intracellular accumulation over the course of the antileishmanial treatment. As expected, a faster peak concentration was reached in plasma compared to PBMCs after the last dose was administered. Intracellular drug quantification in chemotherapy against intracellular pathogens is key to dissect the mechanisms of susceptibility and therapeutic response, since adequate drug levels at the effect site, the cells in which the pathogen survives and replicates, determine the pharmacological activity. Despite this, the relationships between plasma and intracellular drug accumulation remain unknown for leishmaniasis and PK studies rely on plasma drug concentrations assuming these act as surrogates of intracellular concentrations ${ }^{27}$. However, intracellular drug penetration can widely vary depending on host factors such as permeability, local metabolism and drug efflux/uptake transporters activity ${ }^{28}$, which in turn, 
343 determine the level of exposure of intracellular pathogens to drugs. Additionally, multiple reports

344 have shown a link between the host immune response and the antimonial therapy efficacy ${ }^{29}$.

345 Therefore, liking information about intracellular drug concentrations, host immune signals and

346 therapy outcome can provide a powerful framework to optimize therapeutic regimens for Leishmania,

347 as well as for other intracellular pathogens.

349 Acknowledgements

350 We gratefully acknowledge the volunteers who participated in this study and members of the

351 CIDEIM Clinical Unit. Authors declare no conflict of interest. The research reported in this

352 publication was supported by Wellcome Trust 107595/Z/15/Z.

353

354 Data availability

355 The data that support the findings of this study are presented within the manuscript. Clinical data are

356 available on request from the corresponding author; these data are not publicly available due to 357 privacy or ethical restrictions. 


\section{REFERENCES}

362 1. Burza S, Croft SL, Boelaert M. Leishmaniasis. Lancet. 2018;392(10151):951-970.

363 2. World Health Organization. Leishmaniasis. 2020; https://www.who.int/news-room/fact-

364 sheets/detail/leishmaniasis. Accessed April 1, 2020.

$3653 . \quad$ Centers for Disease Control and Prevention. Leishmaniasis, Epidemiology \& Risk Factors.

366 2020; https://www.cdc.gov/parasites/leishmaniasis/epi.html. Accessed May 25, 2020.

367 4. Sundar S, Chakravarty J. An update on pharmacotherapy for leishmaniasis. Expert Opin $368 \quad$ Pharmaco. 2015;16(2):237-252.

3695 5. Ponte-Sucre A, Gamarro F, Dujardin JC, et al. Drug resistance and treatment failure in 370 leishmaniasis: A 21st century challenge. PLoS Negl Trop Dis. 2017;11(12):e0006052.

371 6. Hefnawy A, Berg M, Dujardin JC, De Muylder G. Exploiting Knowledge on Leishmania 372 Drug Resistance to Support the Quest for New Drugs. Trends Parasitol. 2017;33(3):162-174.

373 7. Sundar S, Singh A, Chakravarty J, Rai M. Efficacy and safety of miltefosine in treatment of 374 post-kala-azar dermal leishmaniasis. ScientificWorldJournal. 2015;2015:414378.

375 8. Shaw CD, Carter KC. Drug delivery: lessons to be learnt from Leishmania studies. 376 Nanomedicine-Uk. 2014;9(10):1531-1544.

3779 9. Haldar AK, Sen P, Roy S. Use of antimony in the treatment of leishmaniasis: current status and future directions. Mol Biol Int. 2011;2011:571242.

10. Uliana SRB, Trinconi CT, Coelho AC. Chemotherapy of leishmaniasis: present challenges. Parasitology. 2018;145(4):464-480.

11. Cruz A, Rainey PM, Herwaldt BL, et al. Pharmacokinetics of antimony in children treated for leishmaniasis with meglumine antimoniate. The Journal of infectious diseases. 2007;195(4):602-608.

13. Zaghloul IY, Radwan MA, Al Jaser MH, Al Issa R. Clinical Efficacy and Pharmacokinetics of Antimony in Cutaneous Leishmaniasis Patients Treated With Sodium Stibogluconate. $J$ Clin Pharmacol. 2010;50(11):1230-1237.

14. Reis PG, Abreu AT, Guimaraes AG, Teixeira MC, de Souza J, Silva-Barcellos NM. Development and Validation of an Analytical Method for Quantification of Arsenic and Antimony in Liposomes Using Inductively Coupled Plasma-Optical Emission Spectrometry. J Aoac Int. 2013;96(4):771-775. 
15. PerkinElmer. Tecnical note:The 30-Minute Guide to ICP-MS. 2004-2011; https://www.perkinelmer.com/CMSResources/Images/4474849tch icpmsthirtyminuteguide.pdf. Accessed March 9, 2020.

16. Korvela M, Andersson M, Pettersson J. Internal standards in inductively coupled plasma mass spectrometry using kinetic energy discrimination and dynamic reaction cells. J Anal Atom Spectrom. 2018;33(10):1770-1776.

17. Vanhaecke F, Vanhoe H, Dams R, Vandecasteele C. The Use of Internal Standards in Icp Ms. Talanta. 1992;39(7):737-742.

18. Zhang D, Du A, Wang X, et al. Pharmacokinetics and bioequivalence of two strontium ranelate formulations after single oral administration in healthy Chinese subjects. Xenobiotica. 2019;49(4):457-462.

19. Friedland BA, Hoesley CJ, Plagianos M, et al. First-in-Human Trial of MIV-150 and Zinc Acetate Coformulated in a Carrageenan Gel: Safety, Pharmacokinetics, Acceptability, Adherence, and Pharmacodynamics. J Acquir Immune Defic Syndr. 2016;73(5):489-496.

20. Cashin PH, Ehrsson H, Wallin I, Nygren P, Mahteme H. Pharmacokinetics of cisplatin during hyperthermic intraperitoneal treatment of peritoneal carcinomatosis. Eur J Clin Pharmacol. 2013;69(3):533-540.

21. Fujisawa S, Ohno R, Shigeno K, et al. Pharmacokinetics of arsenic species in Japanese patients with relapsed or refractory acute promyelocytic leukemia treated with arsenic trioxide. Cancer Chemother Pharmacol. 2007;59(4):485-493.

22. Zhou Q, Ruan ZR, Yuan H, Jiang B, Xu DH. Pharmacokinetics and bioequivalence of ranitidine and bismuth derived from two compound preparations. World $J$ Gastroenterol. 2006;12(17):2742-2748.

23. Simiele M, D'Avolio A, Baietto L, et al. Evaluation of the mean corpuscular volume of peripheral blood mononuclear cells of HIV patients by a coulter counter to determine intracellular drug concentrations. Antimicrobial agents and chemotherapy. 2011;55(6):29762978 .

24. Matusiewicz H, Krawczyk M. Determination of total antimony and inorganic antimony species by hydride generation in situ trapping flame atomic absorption spectrometry: a new way to (ultra)trace speciation analysis. J Anal Atom Spectrom. 2008;23(1):43-53.

25. Altunay N, Gurkan R. A new cloud point extraction procedure for determination of inorganic antimony species in beverages and biological samples by flame atomic absorption spectrometry. Food Chem. 2015;175:507-515. 
427 26. dos Santos Ferreira C, Silveira Martins P, Demicheli C, Brochu C, Ouellette M, Frézard F. 428 Thiol-induced reduction of antimony(V) into antimony(III): A comparative study with 429 trypanothione, cysteinyl-glycine, cysteine and glutathione. Biometals. 2003;16(3):441-446.

430 27. Croft SL. Leishmania and other intracellular pathogens: selectivity, drug distribution and PK431 PD [BSP Autumn Symposium "Microbial protein targets: towards understanding and

434 28. Rizk ML, Zou L, Savic RM, Dooley KE. Importance of Drug Pharmacokinetics at the Site intervention", 14th-16th September 2016, University of Durham UK]. Parasitology. of Action. Cts-Clin Transl Sci. 2017;10(3):133-142.

29. Mookerjee Basu J, Mookerjee A, Banerjee R, et al. Inhibition of ABC transporters abolishes antimony resistance in Leishmania Infection. Antimicrobial agents and chemotherapy. 
medRxiv preprint doi: https://doi.org/10.1101/2020.09.15.20194647; this version posted September 18, 2020. The copyright holder for this preprint (which was not certified by peer review) is the author/funder, who has granted medRxiv a license to display the preprint in perpetuity.

It is made available under a CC-BY-ND 4.0 International license .

453

Tables

454 Table 1. Clinical characteristics of CL patients

\begin{tabular}{lc}
\hline Sociodemographic Characteristics & $\mathrm{n}=5$ \\
\hline Age, mean (SD) & $30.2(12.61)$ \\
Sex, No (\%) & $4(80 \%)$ \\
$\quad$ Male & $1(20 \%)$ \\
$\quad$ Female & \\
\hline Race, No. (\%) & $3(60 \%)$ \\
\hline Aborginal & $2(40 \%)$ \\
Mestizo & $3 / 5$ \\
\hline Isolated species & $1 / 5$ \\
\hline Leishmania (Viannia) braziliensis & $1 / 5$ \\
Leishmania (Viannia) panamensis & $5(100 \%)$ \\
Not available & \\
Total & \\
\hline
\end{tabular}

455

456 Table 2. Agilent 7700x operating parameters

\begin{tabular}{ll}
\hline ICP-MS & Setting \\
\hline RF Power & $1550 \mathrm{~W}$ \\
\# of points per peak & 3 \\
Replicates & 3 \\
Integration time/mass & $0.09 \mathrm{~s}\left({ }^{115} \mathrm{In}\right) ; 0.09 \mathrm{~s}\left({ }^{121} \mathrm{Sb}\right)$ \\
Total acquisition time & $1.98 \mathrm{~s}$ \\
Nebulizer/carrier gas flow & $1.05 \mathrm{~L} / \mathrm{min}$ \\
Dilution mode & OFF \\
\hline Integrated Sample Introduction & Setting \\
System (ISIS-DS) & $8 \mathrm{~s}$ \\
\hline Load time & $0.45 \mathrm{rps}$ \\
Load speed & $90 \mathrm{~s}$ \\
Probe rinse time & $30 \mathrm{~s}$ \\
Post rinse time & $0.5 \mathrm{rps}$ \\
Post rinse speed & $2.29 \mathrm{~mm}$ \\
Loop tubing ID &
\end{tabular}


medRxiv preprint doi: https://doi.org/10.1101/2020.09.15.20194647; this version posted September 18, 2020. The copyright holder for this preprint (which was not certified by peer review) is the author/funder, who has granted medRxiv a license to display the preprint in perpetuity.

It is made available under a CC-BY-ND 4.0 International license.

459 Table 3. Calibration curve regression parameters for antimony

\begin{tabular}{|c|c|c|c|c|c|c|}
\hline Run day & Analytical run number & Slope & Intercept & R-Squared & LLOQ & LOQ \\
\hline 1 & 1 & 0.0039481 & 0.0089183 & 0.9966 & 25 & 10000 \\
\hline 1 & 2 & 0.0038862 & 0.0082196 & 0.9979 & 25 & 10000 \\
\hline 40 & 3 & 0.0039172 & 0.018297 & 0.9969 & 25 & 10000 \\
\hline 68 & 4 & 0.0032206 & 0.0037602 & 0.9981 & 25 & 10000 \\
\hline 68 & 5 & 0.0031721 & 0.0065024 & 0.9981 & 25 & 10000 \\
\hline 75 & 6 & 0.0035459 & 0.0058869 & 0.9964 & 25 & 10000 \\
\hline 132 & 7 & 0.00386 & 0.022976 & 0.9953 & 25 & 10000 \\
\hline Mean & & 0.0036500 & 0.0106515 & 0.9970 & & \\
\hline SD & & 0.0003376 & 0.0071493 & 0.0011 & & \\
\hline$\% \mathrm{CV}$ & & 9.25 & 67.12 & 0.11 & & \\
\hline
\end{tabular}

460 Table 4. Back-calculated calibration standards for antimony in human plasma

\begin{tabular}{|c|c|c|c|c|c|c|c|c|}
\hline $\begin{array}{l}\text { Analytical } \\
\text { run } \\
\text { number }\end{array}$ & $\begin{array}{c}25.0 \\
\mathrm{ng} / \mathrm{mL}\end{array}$ & $\begin{array}{c}50.0 \\
\mathrm{ng} / \mathrm{mL}\end{array}$ & $\begin{array}{c}250 \\
\mathrm{ng} / \mathrm{mL}\end{array}$ & $\begin{array}{c}500 \\
\mathrm{ng} / \mathrm{mL}\end{array}$ & $\begin{array}{c}2500 \\
\mathrm{ng} / \mathrm{mL}\end{array}$ & $\begin{array}{r}5000 \\
\mathrm{ng} / \mathrm{mL}\end{array}$ & $\begin{array}{c}7500 \\
\mathrm{ng} / \mathrm{mL}\end{array}$ & $\begin{array}{l}10000 \\
\mathrm{ng} / \mathrm{mL}\end{array}$ \\
\hline \multirow[t]{2}{*}{1} & 21.9 & 48.5 & 246 & 494 & 2390 & 4980 & 7420 & 10300 \\
\hline & 28.0 & 52.2 & 250 & 489 & 2440 & 5210 & 7630 & 10400 \\
\hline \multirow[t]{2}{*}{2} & 23.8 & 50.2 & 238 & 501 & 2470 & 4990 & 7370 & 10600 \\
\hline & 27.1 & 47.2 & 243 & 485 & 2480 & 5180 & 7780 & 10200 \\
\hline \multirow[t]{2}{*}{3} & 23.8 & 45.3 & 247 & 512 & 2420 & 5260 & 7430 & 10600 \\
\hline & 27.6 & 49.0 & 245 & 514 & 2400 & 5180 & 7620 & 9580 \\
\hline \multirow[t]{2}{*}{4} & 26.0 & 49.7 & 252 & 504 & 2510 & 5350 & 7580 & 10700 \\
\hline & 25.1 & 46.3 & 240 & 483 & 2460 & 5050 & 7120 & 9970 \\
\hline \multirow[t]{2}{*}{5} & 24.3 & 47.2 & 246 & 486 & 2500 & 5150 & 7460 & 10400 \\
\hline & 26.6 & 48.7 & 261 & 512 & 2430 & 4880 & 7130 & 10600 \\
\hline \multirow[t]{2}{*}{6} & 23.4 & 49.5 & 249 & 463 & 2260 & 5350 & 7630 & 9410 \\
\hline & 25.7 & 54.0 & 258 & 508 & 2500 & 5200 & 7680 & *13400 \\
\hline \multirow[t]{2}{*}{7} & 23.6 & 50.2 & 254 & 503 & 2390 & 4920 & 7180 & 10900 \\
\hline & 27.8 & 44.2 & 241 & 501 & 2490 & 4830 & 7670 & 10900 \\
\hline Mean & 25.3 & 48.7 & 248 & 497 & 2439 & 5109 & 7479 & 10351 \\
\hline S.D. & 1.92 & 2.61 & 6.69 & 14.3 & 66.2 & 169 & 215 & 462 \\
\hline$\% \mathrm{CV}$ & 7.59 & 5.36 & 2.70 & 2.88 & 2.71 & 3.31 & 2.87 & 4.46 \\
\hline$\%$ Bias & 1.20 & -2.60 & -0.80 & -0.60 & -2.44 & 2.18 & -0.28 & 3.51 \\
\hline $\mathrm{n}$ & 14 & 14 & 14 & 14 & 14 & 14 & 14 & 13 \\
\hline
\end{tabular}

$461 \quad$ Reason for exclusion

$462 *>20 \%$ of acceptance criteria, not in statistics

463

464 Table 5. Accuracy and precision of antimony in human plasma 
medRxiv preprint doi: https://doi.org/10.1101/2020.09.15.20194647; this version posted September 18, 2020. The copyright holder for this preprint (which was not certified by peer review) is the author/funder, who has granted medRxiv a license to display the preprint in perpetuity.

It is made available under a CC-BY-ND 4.0 International license .

\begin{tabular}{lllll}
\hline $\begin{array}{l}\text { Analytical } \\
\text { run number }\end{array}$ & $25.0 \mathrm{ng} / \mathrm{mL}$ & $50.0 \mathrm{ng} / \mathrm{mL}$ & $500 \mathrm{ng} / \mathrm{mL}$ & $7500 \mathrm{ng} / \mathrm{mL}$ \\
\hline 1 & 24.8 & 55.1 & 486 & 7420 \\
& 26.1 & 48.6 & 486 & 7600 \\
& 26.5 & 47.9 & 491 & 7570 \\
& 23.2 & 46 & 510 & 7630 \\
& 24.2 & 50.6 & 495 & 7610 \\
& 26.1 & 50.6 & 498 & 7680 \\
& & & & \\
Mean & 25.2 & 49.8 & 494.0 & 7585 \\
S.D. & 1.30 & 3.13 & 9.05 & 88.71 \\
$\%$ CV & 5.16 & 6.29 & 1.83 & 1.17 \\
$\%$ Bias & 0.80 & -0.40 & -1.20 & 1.13 \\
n & 6 & 6 & 6 & 6 \\
\hline
\end{tabular}

465

466 Table 6. Accuracy and precision of antimony in human PBMCs

\begin{tabular}{lllll}
\hline $\begin{array}{l}\text { Analytical } \\
\text { run number }\end{array}$ & $25.0 \mathrm{ng} / \mathrm{mL}$ & $50.0 \mathrm{ng} / \mathrm{mL}$ & $500 \mathrm{ng} / \mathrm{mL}$ & $7500 \mathrm{ng} / \mathrm{mL}$ \\
\hline 7 & 27.6 & 43.8 & 437 & 6390 \\
& 31.3 & 42.3 & 454 & 6440 \\
& 34.3 & 45 & 446 & 7050 \\
& 28.4 & 44.2 & 420 & 7310 \\
& 29.3 & 44 & 454 & 7450 \\
& & & & \\
Mean & 30.2 & 43.9 & 442 & 6928 \\
S.D. & 2.68 & 3.13 & 9.05 & 88.70 \\
\%CV & 8.88 & 7.14 & 2.05 & 1.28 \\
\%Bias & 20.7 & -12.3 & -11.6 & -7.63 \\
& & & & \\
n & 5 & 5 & 5 & 5 \\
\hline
\end{tabular}

467

468 
medRxiv preprint doi: https://doi.org/10.1101/2020.09.15.20194647; this version posted September 18, 2020. The copyright holder for this preprint (which was not certified by peer review) is the author/funder, who has granted medRxiv a license to display the preprint in perpetuity.

It is made available under a CC-BY-ND 4.0 International license.

$469 \quad$ Figure legends

$470 \quad$ Figure 1. Meglumine antimonate chemical structure

471 Figure 2. Representative calibration curve for antimony in human plasma

472 Calibration standards for antimony $(25,50,250,500,2500,5000,7500$ and $10000 \mathrm{ng} / \mathrm{mL})$ were

473 quantified using ICP-MS and calibration was fitted with a linear model based on weighting of

$4741 /$ concentration2. This calibration was obtained from the analytical run 1 and processed with the

475 software Watson LIMS version 7.5 SP1.

476 Figure 3. Antimony plasma and intracellular concentration-time curves

477 (A-E) Pharmacokinetic curves for antimony plasma and intracellular (PBMCs) levels. Samples

478 were procured from five patients undergoing cutaneous antileishmanial therapy with meglumine

479 antimoniate at the end of the treatment (day 20) and evaluated up to 24 hours following drug

480 administration. 
medRxiv preprint doi: https://doi.org/10.1101/2020.09.15.20194647; this version posted September 18, 2020. The copyright holder for this preprint (which was not certified by peer review) is the author/funder, who has granted medRxiv a license to display the preprint in perpetuity.

It is made available under a CC-BY-ND 4.0 International license

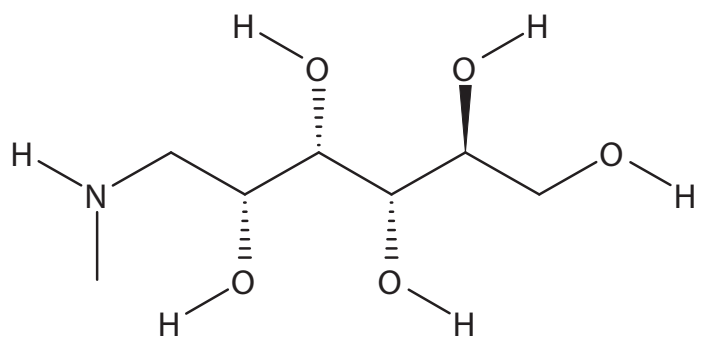<smiles>O=[SH](=O)O</smiles>

Figure 1. Meglumine antimonate chemical structure 


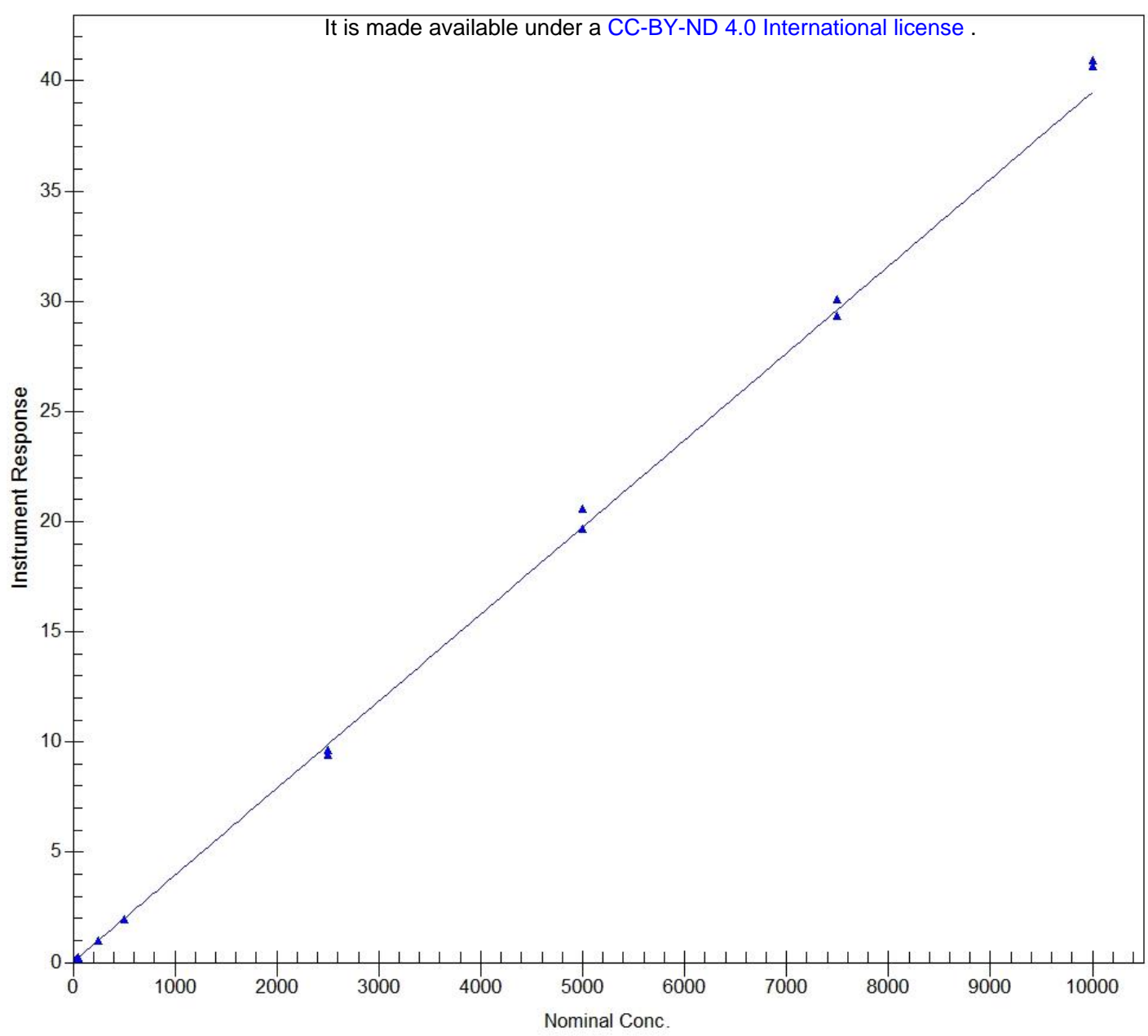

Figure 2. Representative calibration curve for antimony in human plasma

Calibration standards for antimony $(25,50,250,500,2500,5000,7500$ and $10000 \mathrm{ng} / \mathrm{mL})$ were quantified using ICP-MS and calibration was fitted with a linear model based on weighting of $1 /$ concentration $^{2}$. This calibration was obtained from the analytical run 1 and processed with the software Watson LIMS version 7.5 SP1. 
A.

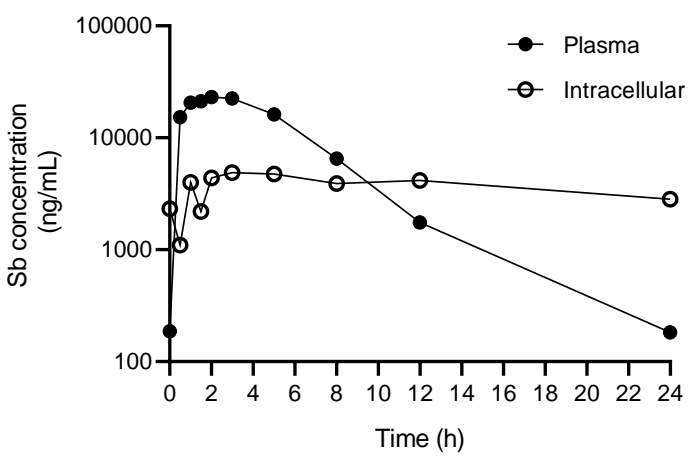

C.

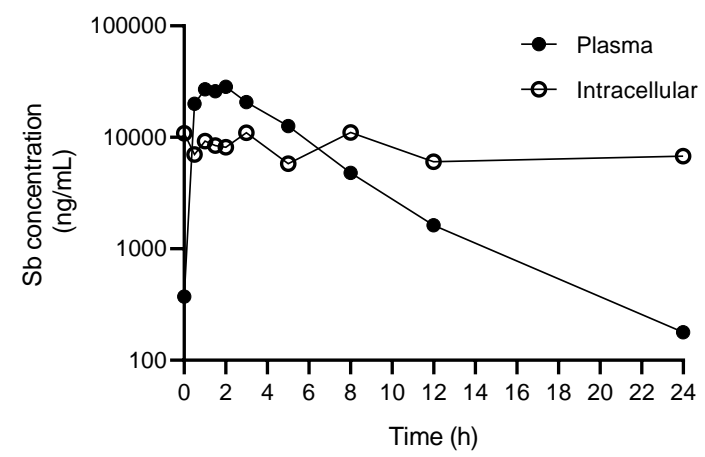

B. BY-ND 4.0 International license.

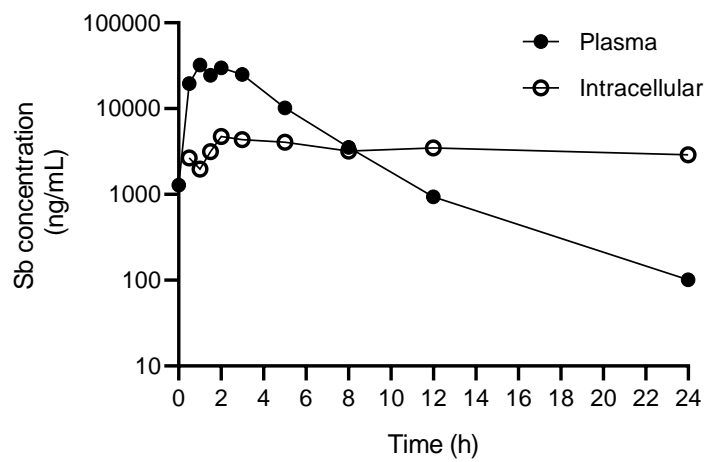

D.

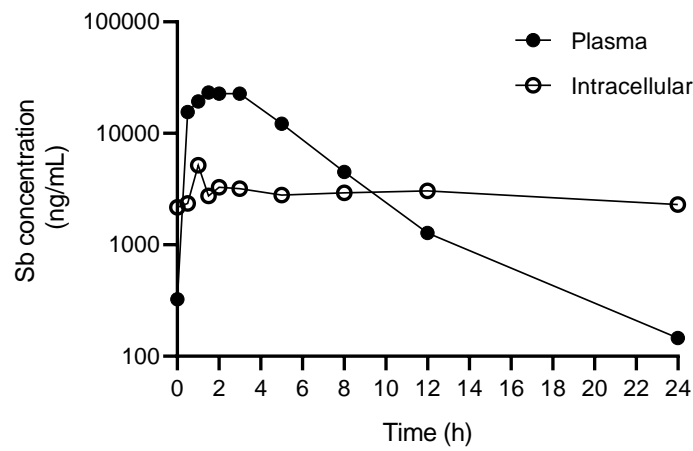

E.

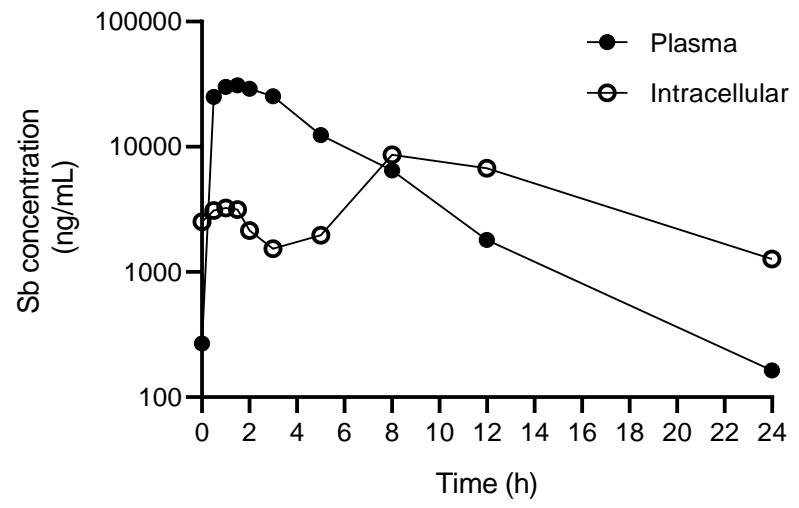

Figure 3. Antimony plasma and intracellular concentration-time curves

(A-E) Pharmacokinetic curves for antimony plasma and intracellular (PBMCs) levels. Samples were procured from five patients undergoing cutaneous antileishmanial therapy with meglumine antimoniate at the end of the treatment (day 20) and evaluated up to 24 hours following drug administration. 